BIBLIOTIKA : Jurnal Kajian Perpustakaan dan Informasi

Volume 2 Nomor 2, 2018

Journal homepage $:$ http://journal2.um.ac.id/index.php/bibliotika

\title{
LITERASI INFORMASI SISWA SEKOLAH MENENGAH PERTAMA DALAM PENGERJAAN TUGAS SEKOLAH
}

\author{
Ligia Riski*, Yunus Winoto, Asep Saeful Rohman \\ Universitas Padjadjaran
}

\begin{tabular}{|c|c|}
\hline A R T I C L E I N F O & A B S T RACT \\
\hline $\begin{array}{l}\text { Article history: } \\
\text { Received: } 24 \text { January } 2018 \\
\text { Accepted: } 2 \text { April } 2018 \\
\text { Published: } 15 \text { Nov } 2018 \\
\text { Keyword: } \\
\text { Literasi informasi, model } \\
\text { big6, pengerjaan tugas, } \\
\text { pembelajaran }\end{array}$ & $\begin{array}{l}\text { Penelitian ini membahas tentang Literasi Informasi Siswa Sekolah } \\
\text { Menengah Pertama dalam Pengerjaan Tugas. Penelitian ini } \\
\text { bertujuan untuk mengetahui kemampuan siswa kelas VIII di SMP } \\
\text { Negeri } 1 \text { Cimahi dalam mengidentifikasi tugas, strategi } \\
\text { penelusuran informasi, penentuan akses informasi, pemanfaatan } \\
\text { informasi, penyusunan dan penyampaian tugas, menilai hasil dan } \\
\text { proses dalam pembelajaran. Metode penelitian ini menggunakan } \\
\text { teknik survey, pengumpulan data dengan kuesioner, observasi } \\
\text { langsung, wawancara dan studi pustaka. Hasil penelitian } \\
\text { menunjukkan bahwa siswa kelas VIII di SMP Negeri } 1 \text { Cimahi } \\
\text { siswa sudah mampu dalam mendefinisikan masalah dan } \\
\text { menggunakan informasi, namun siswa masih dalam kategori } \\
\text { cukup dalam kemampuan strategi pencarian informasi, } \\
\text { mengalokasi informasi, penyusunan tugas dan penilaian hasil dan } \\
\text { proses pembelajaran. }\end{array}$ \\
\hline
\end{tabular}

The research discuss about Literacy of Information of Junior High School Students in Task Force aims to know the ability of VIII students in SMP Negeri 1 Cimahi in identifying tasks, information search strategies, determine information access, use of information, compiling and delivering tasks, assessing results and process in learning for task completion. This research method using survey technique. Data collection techniques using questionnaires, direct observation, interviews and literature study. The result of the research shows that the students of class VIII in SMP Negeri 1 Cimahi have been able to define the problem and use the information, but the students are still in enough category in the ability of information search strategy, information allocation, task formulation and result assessment and learning process.

Informasi pada saat ini sudah menjadi sebuah kebutuhan bagi masyarakat sehingga informasi mengalami pertumbuhan yang terus berkembang. Hal ini mengakibatkan informasi begitu mudah diperoleh, dicari dan ditemukan dalam berbagai bentuk, format, isi dan jenis

\footnotetext{
* Corresponding author.

E-mail addresses: yewefikomunpad@gmail.com (Ligia Riski)
}

ISSN : 2579-3802 (Online) - BIBLIOTIKA : Jurnal Kajian Perpustakaan dan Informasi is licensed under Creative Commons Attribution-ShareAlike 4.0 International License (http://creativecommons.org/licenses/BY/4.0/). 
seakan-akan tidak mengenal batas ruang dan waktu, sehingga fenomena ini dikenal dengan istilah information explosion atau ledakan informasi.

Semakin cepat pertumbuhan informasi didukung juga oleh kemajuan teknologi informasi yang dapat memproduksi informasi yang lebih banyak dan terus mengalami peningkatan. Hal ini setiap individu dihadapkan pada pilihan informasi yang bermacam-macam, namun dalam setiap informasi yang hadir tidak semua informasi dibutuhkan oleh individu, setiap individu tentunya akan memilih informasi yang sesuai dengan kebutuhannya, untuk memperoleh informasi yang sesuai dengan kebutuhan diantara banyaknya informasi yang tersebar maka dibutuhkan kemampuan yang dikenal dengan istilah literasi informasi (Almas, Andajani, \& Istiqomah, 2018; Murti \& Winoto, 2018).

Menurut American Library Association (ALA) dalam laporan hasil seminar FPPTI JabarBanten yang diselenggarakan oleh Perpustakaan Institut Teknologi Telkom (2012)

"Literasi informasi diartikan sebagai kemampuan seseorang untuk mengidentifikasi informasi yang dibutuhkannya, mengakses dan menemukan informasi, mengevaluasi informasi, dan menggunakan informasi secara efektif dan etis".

Penting untuk memiliki literasi informasi disaat sudah terjadi information explosion, individu dapat memperoleh informasi dengan cepat dan tepat serta mendapatkan informasi sesuai dengan kebutuhannya.

Dilihat dari perkembangan informasi yang sangat cepat, maka banyak pula ilmu pengetahuan yang berkembang, oleh karena itu penguasaan literasi informasi sangat penting dalam proses pembelajaran. siswa sebagai pembelajar tentu akan menghadapi keadaan information explosion, siswa sebagai pengguna informasi harus memiliki kemampuan dalam mengenali masalah yang dihadapi, menentukan kebutuhan informasi, mencari informasi, mengakses dan mengalokasi informasi, menggunakan informasi, menggabungkan informasi, mengkomunikasikan informasi, sampai dengan menilai hasil dan proses.

Literasi informasi penting dalam menunjang pendidikan, terutama pada pembelajaran diabad ke 21 yang kini disebut dengan kurikulum 2013 dengan proes pembelajaran berpusat pada peserta didik (student centered learning). Menurut Marseno (2014)

"konsep pembelajaran ini menekankan pada minat, kebutuhan dan kemampuan individu, menjanjikan model belajar yang menggali motivasi instrintik untuk membangun masyarakat yang suka dan selalu belajar".

Hal tersebut tentunya membuat siswa dapat mengembangkan materi secara mandiri baik melalui membaca, observasi, atau diskusi serta aktif untuk mencari infromasi dari berbagai sumber, sehingga dapat memotivasi siswa untuk terus menerus belajar sepanjang hayat (long life learning) lebih jauh dan lebih mendalam. ). Hal ini sejalan dengan literasi informasi yang dapat meningkatkan kualitas sumber daya manusia serta sebagai pembelajaran seumur hidup.

Perpustakaan merupakan salah satu penyedia sumber informasi, siswa dapat memanfaatkan perpustakaan sekolah, karena perpustakaan sekolah memiliki peran yang sangat penting yaitu sebagai sarana penyedia sumber informasi, sarana memperkenalkan perpustakaan kepada siswa, dan sebagai sarana menciptakan siswa yang memiliki literasi informasi (Komariah, 2009). Di Perpustakaan para siswa dapat mengenal literasi informasi, melakukan kegiatan literasi informasi, serta mempelajari tentang literasi informasi.

SMP Negeri 1 Cimahi merupakan salah satu sekolah unggulan di Kota Cimahi. Tentunya sekolah ini memiliki beberapa prestasi yang telah diraih baik dalam bidang akademis maupun non akademis. Untuk mencapai prestasi tersebut tentunya didukung juga oleh fasilitas sekolah salah satunya adalah perpustakaan sebagai sarana yang digunakan oleh siswa untuk mencari sumber - sumber informasi untuk memenuhi kebutuhan informasi, seperti mengerjakan tugas sekolah, belajar, bahkan hanya sekedar membaca. 
Upaya perpustakaan untuk mendukung kegiatan literasi informasi yaitu beberapa guru tidak hanya melaksanakan kegiatan belajar mengajar dikelas saja, beberapa guru melakukan kegiatan belajar mengajar diperpustakaan, agar siswa dapat mencari sumber informasi lebih banyak, belajar secara mandiri melalui diskusi, obervasi dan studi pustaka sehingga dapat mendorong siswa untuk belajar lebih dalam. Tapi dapat dilihat bahwa kemampuan literasi informasi siswa SMP Negeri 1 Cimahi masih belum maksimal, asumsi peneliti dapat dilihat dari hasil observasi yang telah peneliti lakukan dalam KBM, wawancara guru, dan silabus yang tidak memberikan arahan atau menyampaikan tentang literasi informasi. Karena itu siswa belum maksimal dalam mencari kebutuhan informasi serta memanfaatkan informasi secara maksimal.

Oleh karena itu, penelitian ini fokus pada literasi informasi siswa kelas VIII yang sudah dapat beradaptasi dengan lingkungan sekolah terutama diperpustakaan, lebih banyak melakukan kegiatan belajar mengajar dan juga kegiatan diperpustakaan baik pada saat mengerjakan tugas ataupun kegiatan lainnya. Permasalahan yang akan kaji dalam penelitian ini apakah para siswa telah menerapkan literasi informasi dalam mengerjakan tugas dan sejauh mana kemampuan yang dimiliki oleh siswa dalam memenuhi kebutuhan informasinya.

\section{Tinjauan Pustaka}

Literasi informasi pertama kali diperkenalkan oleh pemimpin American Information Industry Association yaitu Paul G. Zurkowski pada tahun 1974 didalam proposalnya yang ditujukan kepada The Nation Commission on Libraries and Information Science (NCLIS). Paul G. Zurkowski dalam Behrenz (1974) menuliskan bahwa:

"People trained in the application of information resources to their work can be called information

literate. They have learned technique and skill for utilizing the wide range of information tools as well as primary sources in molding information solutions for their problems."

Ungkapan dari pernyataan tersebut, bahwa literasi informasi merupakan kegiatan yang mampu menggunakan informasi dengan baik untuk memecahkan masalah.

Hadirnya literasi informasi memberi kemudahan dalam melakukan berbagai hal yang berkaitan dengan informasi. Kini dalam dunia pendidikan sudah dihadapi dengan banyaknya sumber informasi serta kemajuan teknologi yang artinya sudah banyak sumber- sumber informasi yang tersebar dan diterima, hal seperti ini akan membuat seseorang bingung dalam menyaring informasi, karena setiap informasi yang ditemukan isinya akan berbeda, selain itu tidak semua informasi yang tersebar dapat dipercaya dan sesuai dengan kebutuhan, maka dari itu literasi informasi merupakan kemampuan yang penting dimiliki dalam bidang pendidikan.

Menurut UNESCO dalam Wahyu (2014:35) literasi informasi memampukan seseorang untuk menafsirkan informasi sebagai pengguna informasi dan menjadi penghasil informasi bagi dirinya sendiri, UNESCO juga mengatakan bahwa tujuan literasi informasi adalah (1) Memampukan seseorang agar mampu mengakses dan memperoleh informasi mengenai kesehatan, lingkungan, pendidikan, pekerjaan mereka dan lain-lain; (2) Memandu mereka dalam membuat keputusan yang kritikal mengenai kehidupan mereka; (3) Lebih bertanggung jawab kesehatan dan pendidikan mereka.

Seiring dengan adanya literasi informasi, maka dibentuklah model literasi informasi. Model literasi informasi ini memudahkan siapapun penggunanya terutama pada siswa untuk memahami kapan memutuhkan informasi dan bagaimana dapat memilih informasi.peneliti menggunakan model literasi informasi Big6 karena dengan model ini memiliki sifat fleksibel, model ini dapat diterapkan hampir pada masalah yang berkaitan dengan pengambilan keputusan, selain itu proses yang sederhana ini tepat bagi kedua sekolah untuk menerapkannya.

Model ini dikembangkan oleh Michael B. Einsenberg dan Robert E. Berkowitz tahun 1987. Model ini telah dikenal untuk memecahkan masalah serta mengajarkan keahlian informasi. Model Big6 adalah sebuah strategi dalam pemecahan masalah dengan menerapkan model ini peserta didik dapat memecahkan berbagai masalah, pekerjaan rumah, pengambilan keputusan dan tugas sekolah. Menurut Wolf dalam Hariaty (2015) mengatakan bahwa: 
"Dengan menggunakan Big6" ${ }^{\mathrm{TM}}$ siswa dapat membangun cara berpikir yang memudahkan siswa dalam pengerjaan tugasnya dan siswa juga dapat memahami proses yang dilakukan untuk menemukan dan menggunakan informasi yang didapatkan".

Menurut Eisenberg dan Berkowitz dalam Utami (2015) terdapat 6 langkah utama literasi informasi, masing- masing terdiri dari 2 sub. Berikut 6 langkah utama literasi informasi yang terdapat dalam tabel dibawah ini :

Tabel 1 Enam Langkah Utama Literasi Informasi

\begin{tabular}{|r|l|}
\hline 1. Definisi tugas & $\begin{array}{l}\text { 1.Mendefinisikan masalah informasi } \\
\text { 2.Mengidentifikasi kebutuhan informasi }\end{array}$ \\
\hline 2. Strategi pencarian informasi & $\begin{array}{l}\text { 1. Memilih sumber } \\
\text { 2. Menentukan sumber terbaik }\end{array}$ \\
\hline 3. Alokasi dan akses & $\begin{array}{l}\text { 1. Mengalokasi sumber secara isi dan fisik } \\
\text { 2. Menemukan informasi dalam sumber sumber yang ada }\end{array}$ \\
\hline 4. Menggunakan informasi & $\begin{array}{l}\text { 1. Menghubungkan informasi } \\
\text { 2. Menyarikan informasi yang relevan }\end{array}$ \\
\hline 5. Sintesa & $\begin{array}{l}\text { 1. Mengorganisasikan informasi } \\
\text { 2. Mempresentasikan informasi }\end{array}$ \\
\hline 6. Evaluasi & $\begin{array}{l}\text { 1. Mengevaluasi hasil } \\
\text { 2. Mengevaluasi proses }\end{array}$ \\
\hline
\end{tabular}

(Sumber : skripsi Widya Utami, 2015)

\section{METODE}

Penelitian ini menggunakan pendekatan kuantitatif dimana data hasil penelitian berupa angka dengan analisis deskriptif. Menurut Bungin (2005:44)

"Penelitian kuantitatif dengan analisis deskriptif bertujuan untuk menggambarkan, meringkaskan berbagai kondisi, berbagai situasi, atau berbagai variabel yang timbul di masyarakat yang menjadi objek penelitian itu berdasarkan apa yang terjadi"

Metode yang digunakan adalah metode penelitian survei, dengan metode ini peneliti akan memaparkan secara jelas mengenai literasi informasi siswa. Tujuan utama peneliti dengan menggunakan metode survei yaitu untuk mengetahui gambaran umum karakteristik dari populasi. Menurut Sugiyono (2016) "metode survei digunakan untuk mendapatkan data dari tempat tertentu yang alamiah" artinya, penelitian ini murni mengetahui gambaran dari populasi, oleh sebab itu peneliti melakukan pengumpulan data kepada responden dengan cara menyebarkan kuesioner, test, wawacara tersturktur dan sebagainya. Untuk teknik analisis data terdapat analisis data statistika deskriptif, yang terdiri dari analisis data responden dan analisis data penelitian.

Penelitian ini dilaksanakan di SMPN 1 Cimahi yang beralamat di Jl. Raden Embang Artawidjaja No.12 Cimahi.

\section{HASIL DAN PEMBAHASAN}

\section{Mengidentifikasi Tugas}

Bagi sub variabel pertama, yaitu mengenai mengidetifikasi tugas terdiri dari dua indikator mendefinisikan masalah dan mendefinisikan kebutuhan informasi dengan hasil skor 1061 yang sudah berada dalam kategori mampu. Hal ini menunjukan bahwa siswa kelas VIII SMP Negeri 1 Cimahi sudah mampu mengetahui masalah apa yang sedang dihadapi dan akan melakukan apa untuk menyelesaikan masalah tersebut dengan melakukan beberapa aktifitas yang sesuai dengan literasi informasi seperti membuat catatan ketika diberi tugas oleh guru dan bertanya kembali kepada guru untuk memperjelas apa yang diinstruksikan oleh guru, brainstorming baik dalam mengajukan pertanyaan, berdiskusi dengan teman atau kelompok dan melalui visualisasi pemikiran dengan membuat pertanyaan $5 \mathrm{~W}+1 \mathrm{H}$ (what, when, who, why, where, dan how). 


\section{Strategi Pencarian Informasi}

Sub variabel kedua, yaitu mengenai strategi pencarian informasi yang terdiri dari dua indikator memilih sumber dan menentukan sumber terbaik dengan hasil skor 2004 masuk pada kategori cukup. Hal ini menunjukan bahwa siswa kelas VIII SMP Negeri 1 Cimahi cukup dalam strategi penelusuran informasi untuk memperoleh informasi yang dapat digunakan untuk menyelesaikan tugas dengan melakukan beberapa kegiatan seperti, membuat daftar sumber informasi, siswa mengetahui sumber informasi yang akan digunakan, siswa menggunakan sumber media cetak ataupun digital, siswa mengetahui lokasi dimana sumber informasi dapat ditemukan, siswa mengetahui cara mencari informasi dengan efektif, meminta bantuan pustakawan atau kepada guru, siswa membaca penanggung jawab informasi ( penulis, pencipta karya dan sebagainya) dan untuk mempercayai sebuah sumber informasi siswa melihat dari kemutakhiran, kelengkapan dan keakuratan informasi tersebut.

\section{Alokasi dan Akses Informasi}

Sub variabel ketiga, yaitu alokasi dan akses informasi yang terdiri dari dua indikator mengalokasi sumber secara intelektual dan fisik, memperoleh informasi melalui sumber tersebut dengan hasil skor 1227 yang berada dalam kategori cukup. Hal ini menunjukan bahwa siswa kelas VIII SMP Negeri 1 Cimahi cukup untuk mengalokasi dan mengakses informasi, hal ini membuktikan bahwa siswa memanfaatkan dan menggunakan alat bantu untuk pencarian sumber informasi dan siswa pun tahu beragam alat bantu pencarian informasi, siswa dapat menggunakan alat bantu tersebut untuk menemukan informasi yang dicarinya. Siswa melakukan beberapa kegiatan dalam tahap ini seperti menggunakan e-katalog atau kartu katalog, menelusuri sumber informasi online dengan cara mendownload, menggunakan cara pencarian informasi dengan kata kunci, judul, pengarang ataupun menggunakan boolean, menggunakan indeks, abstrak, daftar isi dan sebagainya untuk menemukan informasi yang efektif, menggunakan sumber referensi untuk menemukan sumber informasi.

\section{Menggunakan Informasi}

Sub variabel keempat, yaitu menggunakan informasi yang terdiri dari dua indikator yang menghubungkan informasi dan mencari informasi yang relevan dengan hasil skor 1324 yang sudah berada dalam kategori mampu. Hal ini menunjukan bahwa siswa kelas VIII SMP Negeri 1 Cimahi mampu dihadapkan pada masalah pemilihan cara yang efektif untuk menyeleksi informasi yang sudah diperoleh dan siap digunakan sebagai panduan dalam mengerjakan tugas. Siswa melakukan beberapa aktifitas dalam kegiatan ini seperti, membuat catatan kutipan dari sumber informasi yang telah dipilih, mengambil informasi yang relevan, mencari kembali informasi, membuat catatan atau rangkuman dari sumber informasi yang telah ditemukan.

\section{Menggabungkan Tugas}

Sub variabel kelima yaitu, menggabungkan tugas yang terdiri dari dua indikator mengorganisasikan informasi dari berbagai sumber dan mempresentasikan hasil dari produk akhir (tugas) dengan hasil skor 1003 yang berada dalam kategori cukup. Hal ini menunjukan bahwa siswa kelas VIII SMP Negeri 1 Cimahi cukup dalam mengorganisasikan informasi dari berbagai sumber dan mempresentasikan hasil dari produk akhir (tugas), dengan melakukan beberapa aktifitas seperti, membandingkan, mengelola, menyusun dan menggabungkan informasi yang sudah diperoleh dalam mengerjakan tugas, informasi yang telah diperoleh dari sumber informasi lain atau milik orang lain harus diakui dengan mencantumkan dalam kutipan atau bibliografi, membuat draft, membuat catatan bibliografi, menyajikan tugas dengan cara presentasi kepada audiens menggunakan media yang sesuai.

\section{Menilai Hasil dan Proses}

Sub variabel keenam menilai hasil dan proses yang terdiri dari dua indikator yaitu mengevaluasi hasil dan mengevaluasi proses dengan hasil skor 1203 yang berada dalam kategori cukup. Hal ini menunjukan bahwa siswa kelas VIII SMP Negeri 1 Cimahi cukup untuk 
memberikan penilaian terhadap hasil dan proses yang telah dilaluinya. Ketika siswa melakukan kegiatan ini, siswa dapat mengukur hasil penemuan dan pemanfaatan informasi yang telah digunakan apakah informasi yang telah selesai menjadi tugas memiliki guna atau tidak. Siswa melakukan beberapa kegiatan dalam tahap ini seperti, mengajukan pertanyaan kepada diri sendiri, memeriksa kembali tugas yang sudah dikerjakan, melakukan pemanfaatan informasi dengan menyimpan sumber informasi, meminta pendapat orang lain untuk memberikan saran, mengevaluasi langkah- langkah yang dilakukan siswa dalam kegiatan literasi informasi, dan siswa dapat menarik pelajaran dari hasil dan proses yang siswa lakukan untuk dijadikan sebuah pengalaman.

\section{PENUTUP}

\section{Simpulan}

Berdasarkan hasil penelitian dan analisis data yang telah dilakukan oleh peneliti, maka peneliti akan memberikan kesimpulan mengenai "Literasi Informasi Siswa Sekolah Menengah Pertama, yang mengacu pada tujuan penelitian, maka dapat disimpulkan beberapa hal yaitu :

Pada tahap mendefinisikan tugas, siswa SMP Negeri 1 Cimahi sudah mampu melakukan kegiatan yang diperlukan dalam tahap ini, seperti angkah awal untuk mendefinisikan masalah informasi dengan mencatat informasi yang didapat, bertanya kembali apabila informasi masih samar- samar, melakukan brainstorming baik berdiskusi dengan teman sekelas ataupun menuliskan pertanyaan $5 \mathrm{~W}+1 \mathrm{H}$ (what) apa yang akan dijadikan judul dalam karya tulis ini, apa topik yang ada dalam bacaan, (who) siapa yang akan membaca karya tulis ini, (where) dimana saya dapat menemukan sumber informasi atau referensi yang sesuai dengan judul karya tulis ini, (when) kapan peristiwanya terjadi , (why) mengapa judul ini yang digunakan dalam karya tulis, (bow) bagaimana judul ini dapat dimengerti oleh orang lain, bagaimana cara mengungkapkan kejadian ini.

Pada tahap pencarian strategi informasi, siswa SMP Negeri 1 Cimahi sudah cukup melakukan kegiatan yang perlu dilakukan. Siswa membuat daftar informasi, siswa mengetahui sumber informasi yang akan digunakan, menggunakan dan memanfatkan berbagai media sebagai sumber informasi, memanfaatkan perpustakaan sebagai tempat pencarian sumber informasi, meminta bantuan kepada pustakawan, membaca indentitas informasi yang terdiri dari identitas penulis, tanggal dan tahun terbitnya sumber informasi, penerbit, tempat terbit, dan sebagainya serta melihat informasi dari kemutakhiran, kelengkapan dan keakuratan.

Pada tahap alokasi dan akses informasi, siswa SMP Negeri 1 Cimahi sudah cukup untuk melakukan kegiatan yang diperlukan dalam tahap ini, seperti memanfaatkan alat bantu yang berada diperpustakaan kartu katalog atau e-katalog, mendownload artikel atau jurnal dari internet, menelusuri pencarian informasi dengan cara yang efektif, memanfaatkan abstrak, indeks, kata pengantar untuk menemukan informasi dan memanfaatkan sumber referensi lainnya untuk mengakses informasi yang dibutuhkan.

Pada tahap menggunakan informasi, siswa SMP Negeri 1 Cimahi sudah mampu untuk melakukan kegiatan yang diperlukan dalam tahap ini, seperti membuat catatan kutipan, menganalisis informasi dengan pertanyaan brainstorming $5 \mathrm{~W}+1 \mathrm{H}$ (what, who, where, when, why, and how), memutuskan informasi yang relevan, mencari kembali informasi untuk memenuhi pengerjaan tugas dan membuat catatan rangkuman.

Pada tahap penyusunan tugas, siswa SMP Negeri 1 Cimahi sudah cukup untuk melakukan beberapa aktifitas, seperti membaca kembali catatan kutipan atau rangkuman lalu menggabungkan dengan gagasannya untuk dituangkan dalam penyusunan tugas, membuat kerangka tugas (draft), menuliskan sumber dari mana informasi berasal, dan memilih media yang tepat untuk mengkomunikasikan hasil produk akhir (tugas) kepada orang lain.

Pada tahap menilai hasil dan menilai proses, siswa SMP Negeri 1 Cimahi sudah cukup untuk melakukan beberapa aktifitas, seperti membaca kembali untuk pemahaman secara lebih lanjut sebelum tugas dikumpulkan, menyimpan sumber informasi sebagai pemanfaatan sumber 
informasi, meminta pendapat dan saran kepada guru atau pustakawan, menilai diri sendiri dalam proses belajar, dan menarik pelajaran dari yang telah dikerjakan.

\section{Saran}

Berdasarkan kesimpulan yang telah dipaparkan oleh peneliti dan hasil penelitian yang telah diperoleh, maka peneliti akan menyampaikan saran sebagai berikut.

Terlihat dari empat sub variabel yang berada dalam kategori cukup, menandakan bahwa siswa perlu diberikan pembelajaran tentang literasi informasi, sebagai metode belajar secara mandiri dan efektif, karena literasi informasi akan berkaitan dengan kehidupan sehari- hari dan sangat berguna dalam setiap aspek kehidupan.

Pustakawan dan guru diharapkan dapat meningkatkan pengetahuannya tentang literasi informasi, sehingga dalam pembelajaran literasi dapat dilaksanakan dengan maksimal. Beberapa cara agar pustakawan dan guru dapat meningkatkan pengetahuan tentang literasi sekolah, misalnya bergabung dengan ATPUSI (Asosiasi Tenaga Perpustakaan Sekolah) atau mengikuti beberapa kegiatan seperti pelatihan dan seminar, dan mengikuti panduan GLS (Gerakan Literasi Sekolah) dari Kementrian Pendidikan.

Perpustakaan sebagai sarana utama dalam program literasi informasi, diharapkan dapat menjadi efektif untuk digunakan dalam pembelajaran oleh siswa. Perpustakaan dapat membuat program kunjungan wajib ke perpustakaan yang diberikan jadwal pada setiap kelas, perpustakaan dapat membuat kegiatan memperkenalkan literasi informasi dalam kegiatan belajar mengajar. Dalam kegiatan ini, pustakawan dan guru dapat bekerja sama untuk memberikan pelajaran literasi informasi kepada siswa. Perpustakaan juga perlu meningkatkan kualitas pelayanan, fasilitas dan pengadaan sumber informasi. untuk menunjang pembelajaran, agar lebih optimal.

\section{DAFTAR PUSTAKA}

Almas, H., Andajani, K., \& Istiqomah, Z. (2018). Hubungan Kebutuhan Informasi Mahasiswa Program Studi Ilmu Perpustakaan dalam Penyelesaian Skripsi dengan Ketersediaan Koleksi. BIBLIOTIKA : Jurnal Kajian Perpustakaan dan Informasi, 2(1), 63-71.

Arikunto, S. (2002). Prosedur Penelitian Suatu Pendekatan Praktek. Yogyakarta: Rineka Cipta.

Bara, A. K. B. (2014). Literasi Informasi di Perpustakaan. Jurnal Iqra' (Mei). jurnal.uinsu.ac.id/index.php/iqra/article/download/67/223 (diakses tanggal 2 Februari 2017)

Basuki, S. (1993). Pengantar Ilmu Perpustakaan. Jakarta: Gramedia Pustaka Utama.

Bungin, B. (2005). Metode Penelitian Kuantitatif: Komunikasi, Ekonomi, dan Kebijakan Publik Serta Ilmu Ilmu Sosial Lainnya”. Jakarta: Kencana.

Darmawan, D. (2014). Metode Penelitian Kuantitatif. Bandung: Remaja Rosdakarya

Darrow, R. (2005). Big6 Stage-3-Location and Access Treasure Hunting. http://www.linworth.com/ (diakses tanggal 5 Agustus 2017)

Departemen Pendidikan Nasional. (2003). Undang-Undang Nomor 20 Tahun 2003, Tentang Sistem Pendidikan Nasional. Jakarta: Depdiknas

Eisenberg, M. B. (2005). It All Starts with Task Definition. Library Media Connection (AugustSeptember). http://www.linworth.com/ (diakses tanggal 5 Agustus 2017)

Eisenberg, M. B. (2005). Stage 2-Information Seeking Strategies. http://www.linworth.com/ (diakses tanggal 5 Agustus 2017)

Eisenberg, M B. (2005). It All Starts with Task Definition. http://www.linworth.com/ (diakses tanggal 5 Agustus 2017)

Eisenberg, M B. (2005). Use of Information: Getting to the Heart of the Matter. http://www.linworth.com/ (diakses tanggal 5 Agustus 2017)

Eisenberg, M. B. (2005). Synthesis-WhereIt All Comes Together. http://www.linworth.com/ (diakses tanggal 5 Agustus 2017) 
Eisenberg, M. B. (2005). Evaluation- Cheking It All Out. http://www.linworth.com/ (diakses tanggal 5 Agustus 2017)

Hamdi, A. S dan F Bahruddin. (2014). Metode Penelitian Kuantitatif Aplikasi Dalam Pendidikan. Yogyakarta: Deepublish.

Hasugian, J. (2008). Urgensi Literasi Informasi dalam Kurikulum Berbasis Kompetendi di Perguruan Tinggi. Jurnal Studi Perpustakaan dan Informasi (Desember). puslit2.petra.ac.id/ejournal/index.php/pus/article/download/17231/17184 (diakses tanggal 4 Maret 2017)

Kalida, M dan Moh. Mursyid. (2014). Gerakan Literasi Mencerdaskan Negeri. Yogyakarta: Aswaja Pressindo.

Kementerian Pendidikan dan Kebudayaan. (2016). Panduan Gerakan Literasi Sekolah. Jakarta: Direktorat Jenderal Pendidikan Dasar dan Menengah Kementerian Pendidikan dan Kebudayaan.

Komariah, N. (2009). Peran Perpustakaan Sekolah dalam Proses Belajar Mengajar. disampaikan pada: Semiloka Pemberdayaan Perpustakaan Sekolah MTs Salafiyah Karangsari Leuwigoong Garut. repository.unpad.ac.id/6222/1/peranan_perpustakaan_sekolah.pdf (diakses tanggal 10 Agustus 2017)

Lien, Diao ai dkk. (2010). 7 Langkah Knowledge Management. Jakarta: Universitas Atma Jaya.

Marseno, R. (2014). Identifikasi Literasi Informasi dalam Rangka Pengembangan Kurikulum Sekolah Dasar. Skripsi. Institut Pertanian Bogor.

Murti, D. P., \& Winoto, Y. (2018). HUBUNGAN ANTARA KEMAMPUAN LITERASI INFORMASI DENGAN PRESTASI BELAJAR SISWA SMAN 1 CIBINONG KABUPATEN BOGOR. BIBLIOTIKA : Jurnal Kajian Perpustakaan dan Informasi, 2(1), 1 5.

Naibaho, K dan Clara. (2007). Menciptakan Generasi Literat Melalui Perpustakaan. Artikel.eprints.rclis.org/12549/1/Menciptakan_Generasi_Literat_Melalui_Perpustakaan. pdf (diakses tanggal 9 agustus 2017)

Nurohman, A. (2014). Signifikansi Literasi Informasi (Information Literacy) dalam Dunia Pendidikan diera Global. Jurnal Kependidikan (Mei 1). ejournal.iainpurwokerto.ac.id/index.php/jurnalkependidikan/article/view/537(diakses tanggal 2 Februari 2017).

Rohmah, U. P. (2013). Literasi Informasi Siswa Kelas XII SMA Negeri 59 Jakarta dalam Proses Belajar. Skripsi. Universitas Padjajaran.

Seminar FPPTI Jabar-Banten. (2011). Literasi Informasi dan Plagiarisme. Laporan Hasil Seminar. http://docplayer.info/30983047-Laporan-hasil-seminar-fppti-jabar-banten-mengenailiterasi-informasi-dan-plagiarisme.html (diakses tanggal 15 Agustus 2017)

Setiawan, V. (2017). Strategi Komuniasi Pustakawan Dalam Implementasi Literasi Informasi. Jurnal Penelitian Komunikasi dan Opini Publik (Juni). https://jurnal.kominfo.go.id/index.php/jpkop/article/download/948/597(diakses tanggal 4 Maret 2017)

Setyo, D dan Dessy A. (2015). Pengaruh Kualitas Informasi dan Kualitas Sistem Informasi Terhadap Kepuasan Serta Kinerja Pengguna Sistem Informasi. Efektif Jurnal Bisnis dan Ekonomi (Juni 1). jurnalefektif.janabadra.ac.id/wp-content/uploads/2015/.../EFEKTIFJUNI-2015_4.pdf (diakses tanggal 30 Agustus 2017).

Siswono, T. Y dan Whidia N. (2014). Meningkatkan Kemampuan Berpikir Kreatif Siswa Melalui Pemecahan Masalah "What's Another Way". ejournal.unp.ac.id/students/index.php/pmat/article/download/1152/844 (diakses tanggal 9 juli 2017)

Sofa, N. (2010). Penerapan Literasi Informasi di Sekolah Alam Indonesia Rawa Kopi. Skripsi. Universitas Indonesia. 
S, Yoanna Hariaty. (2015). Analisis Literasi Informasi Pada Siswa Homescholling Kak Seto Medan. Skripsi. Universitas Sumatera Utara.

Suadi, D dan Testiani M. (2015). Revolusi Sumber Informasi Digital. Yogyakarta: Bulaksumur Empat. Sugiyono. (2010). Metode Penelitian Kuantitatif Kualitatif dan R\&D. Bandung: Alfabeta.

Surachman, A. (2010). Perpustakaan Sekolah Sebuah Elemen Penting dalam Keberhasilan Pendidikan dan Pembelajaran di Sekolah. Makalah. https://repository.ugm.ac.id/136175/1/Makalah-PerpSekolah-2010.pdf (diakses tanggal 9 Agustus 2017

Trirahayu, W. W. (2014). Literasi Informasi dalam Kajian Seni dikalangan Seniman Muda Bandung New Emergence. Skripsi. Universitas Padjajaran.

Undang-Undang Republik Indonesia Nomor 43 Tahun 2007 tentang Perpustakaan. Jakarta: Perpustakaan Nasional RI

Widia, U. (2015). Literasi Informasi Siswa dalam Pembelajaran Berbasis Kurikulum 2013. Skripsi. Universitas padjadjaran.

Wijayanty, E. (2012). Kemampuan Literasi Informasi Siswa di SMP Negeri 4 Depok. Skripsi. Universitas Indonesia. 